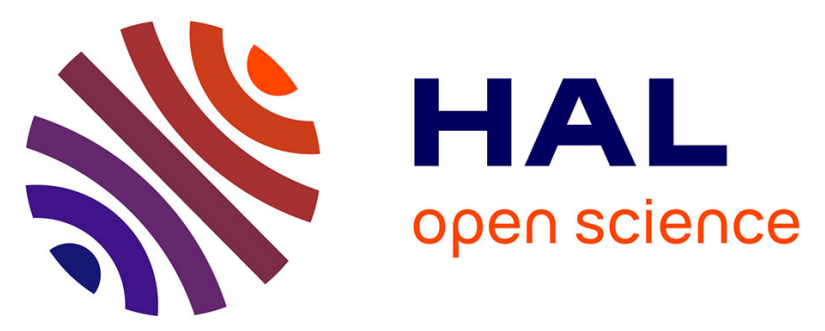

\title{
Topical 1\% 5-Fluoruracil in Ocular Surface Squamous Neoplasia: a Long-term Safety Study
}

Raffaele Parrozzani, Daniela Lazzarini, Ernesto Alemany-Rubio, Francesca Urban, Edoardo Midena

\section{- To cite this version:}

Raffaele Parrozzani, Daniela Lazzarini, Ernesto Alemany-Rubio, Francesca Urban, Edoardo Midena. Topical 1\% 5-Fluoruracil in Ocular Surface Squamous Neoplasia: a Long-term Safety Study. British Journal of Ophthalmology, 2010, 95 (3), pp.355. 10.1136/bjo.2010.183244 . hal-00567053

\section{HAL Id: hal-00567053 https://hal.science/hal-00567053}

Submitted on 18 Feb 2011

HAL is a multi-disciplinary open access archive for the deposit and dissemination of scientific research documents, whether they are published or not. The documents may come from teaching and research institutions in France or abroad, or from public or private research centers.
L'archive ouverte pluridisciplinaire HAL, est destinée au dépôt et à la diffusion de documents scientifiques de niveau recherche, publiés ou non, émanant des établissements d'enseignement et de recherche français ou étrangers, des laboratoires publics ou privés. 
Topical 1\% 5-Fluoruracil in Ocular Surface Squamous Neoplasia: a Long-term Safety Study.

Raffaele Parrozzani MD ${ }^{\text {a; }}$ Daniela Lazzarini ${ }^{\text {a }}$; Ernesto Alemany-Rubio ${ }^{\text {b, c }}$; Francesca Urban ${ }^{\text {b; }}$ Edoardo Midena MD ${ }^{a, b}$.

${ }^{a}$ Fondazione GB Bietti per l'Oftalmologia, IRCCS, Via Livenza 3, 00198, Roma, Italy.

${ }^{\mathrm{b}}$ Department of Ophthalmology, University of Padova, Via Giustiniani 2, 35128, Padova, Italy.

${ }^{c}$ Cuban Eye Institute, "Ramon Pando Ferrer", University of Habana, Avenida 76 y 146, La Habana, Cuba.

Corresponding Author: Edoardo Midena, MD,

Departement of Ophthalmology, University of Padova,

Via Giustiniani 2, Padova 35128, Italy;

e-mail: edoardo.midena @unipd.it

Phone: +39 049821 2121; Fax: +39 0498212129

Keywords: Ocular surface, neoplasia; drugs; cornea; conjunctiva.

Word count: 1955

This paper was partially presented at the International Congress of Ocular Oncology, 8th-12th September 2009, Cambridge, United Kingdom. 


\section{ABSTRACT}

Background/aims: The aim of this study was to evaluate long-term corneal toxicity of topical chemotherapy with $1 \% 5$-Fluoruracil (5-FU) as a sole or adjuvant treatment of ocular surface squamous neoplasia (OSSN).

Methods: Forty-one consecutive cases of OSSN were included in this prospective study. Patients underwent topical chemotherapy with 1\% 5-FU four times/day for 4 weeks (one course). Adjunctive courses were were repeated until clinical and cytological tumor regression. Clinical confocal microscopy (CCM) (Confoscan 4.0, Nidek Co Ltd, Gamagori, Japan) was used to check for 5-FU long-term corneal toxicity.

Results: Mean follow-up was 89.7 \pm 14.4 months (range, 63-122 months). Twenty-two patients (53.7\%) underwent topical 5-FU as a sole treatment, whereas nineteen patients (46.3\%) as adjuvant and/or debulking therapy. Mean number of 5-FU cycles was 1.9 (range, 1-5 cycles). Three tumors $(7,3 \%)$ treated with 5-FU alone recurred during follow-up. Recurrences were successfully treated with additional 5-FU courses. CCM showed no long-term difference between treated eye and fellow (control) eye in: endothelial cells count, pleomorphism and polymegatism, anterior stromal keratocyte density, sub-basal nerve plexus fibre number, density, and beadings and central cornea epithelium thickness ( $p=n . s$.$) .$

Conclusion: Topical 5-FU, as a sole or combined therapy, must be considered a long-term safe and effective treatment for patients affected by OSSN. 


\section{INTRODUCTION}

Ocular surface squamous neoplasia (OSSN) is a spectrum of disease with the potential of visual loss and local morbidity.[1] OSSN are traditionally seen in Caucasian older male or in lighter skinned populations in tropical countries.[1-2] Risk factors for this disease include: ultraviolet light exposure, petroleum products, cigarette smoking, human papillomavirus and human immunodeficiency virus infection.[3] The term OSSN encompasses corneo-conjunctival intraepithelial neoplasia (CIN) and invasive squamous cell carcinoma (SCC).[4] These lesions are commonly seen in the exposed corneo-conjunctival areas and described as being slightly elevated, variably shaped, relatively sharply demarcated from the surrounding normal tissues, accompanied by feeding blood vessels and having from pearly gray to reddish gray appearance.[1] Surgical excision with adjunctive cryotherapy was formerly considered the treatment of choice.[5] However, recurrence rates after surgery are significant, even when free surgical margins were achieved.[5] Topical chemotherapy has become a valuable therapeutic option for the treatment of ocular surface tumors in the last decade. 5-Fluoruracil (5-FU), Mitomicyn C (MMC) and Interferon $\alpha 2 b$ (INF $\alpha$ ) have been introduced, and are currently widely used, as both adjuvant therapy (to prevent tumor recurrence) and primary treatment of OSSN.[6-8] Although many reports suggest a shortterm safety of topical chemotherapy with $1 \% 5-\mathrm{FU}$, only few data were reported on a long-term base.[6, 9, 10] Moreover, morphologic and morphometric analysis of corneal layers was never performed in-vivo, at microscopic level, after topical chemotherapy. The aim of this study was to evaluate long-term corneal toxicity of topical chemotherapy with $1 \% 5-\mathrm{FU}$, as a sole or adjuvant treatment of OSSN, using Clinical Confocal Microscopy (CCM).

\section{MATERIAL AND METHODS}

This study complied with the tenets of the Declaration of Helsinki and was approved by the IRB of our Institution. Each patient was recruited from those referred to the Ophthalmic Oncology Unit of our Departments and underwent a baseline full ophthalmologic examination. Clinical and demographic characteristics were collected, including: age, gender, tumor location (cornea, conjunctiva, corneo-conjunctival) and tumor largest basal diameter. Adjunctive tumor clinical features such as nodularity, mutifocality, prominent vascularization (presence of macroscopically evident tumor vessels or conjunctival feeder vessels) and fornix involvement were also reported. 
[2] Tumor clinical aspect was documented by anterior segment photography. Cytologic analysis (scraping technique) was obtained from all patients and reported as low-grade dysplasia (cells with enlarged nuclei, hyperchromasia and irregular contour of the nuclear membrane with increased nuclear/cytopasmic ratio) or high-grade dysplasia (pleomorphism of the nucleus with dyskeratotic cells.[1] The presence of syncytial sheath, nucleoli and infiltration of inflammatory cells was reported as invasive SCC.[1] Each patient was treated with 1\% 5-FU as a sole or in a surgical combined approach. Our standard protocol consists in topical instillation of $1 \% 5$-FU prepared in aqueous solution and administered four times a day during the course of 4 weeks (one course).[6, 9] Patients were instructed about possible 5-FU local side effects. After instillation of the eyedrops the inferior lacrimal punctum was briefly occluded and an eye ointment was applied on the inferior eyelid skin to minimise skin contact with the drug. A new medication bottle was used for one entire course and than returned to the pharmacy. Adjunctive courses were administered after three months of free interval and repeated until clinical and cytological tumor regression. Patients treated with topical chemotherapy as a combined treatment underwent wide surgical excision followed by cryotherapy to the cut edges of the conjunctiva. Alcohol epitheliectomy was performed for corneal involvement. Large tissue defects were managed by amniotic membrane reconstruction of the ocular surface. Topical chemotherapy was administered at least three weeks after surgery, following our standard protocol. [6, 9] Follow-up was performed monthly until clinical resolution, after 1, 3, and 6 months and every 6 months thereafter. Follow-up included full ophthalmologic examination, slit lamp biomicroscopy and anterior segment photography. Scraping cytology was also performed after 1 and 6 months of complete clinical tumor regression. Follow-up was longer than 5 years.

\section{Corneal confocal microscopy}

In-vivo corneal multi-layer analysis was performed using clinical confocal microscope Confoscan 4.0 (Nidek Co Ltd, Gamagori, Japan) equipped with a 40X immersion objective lens (Zeiss Inc, Oberkochen, Germany) and the Z-ring adapter system designed for full thickness examination of the cornea. Inclusion criteria were: patients affected by OSSN, treated with 1\% 5-FU (as a sole or combined therapy), with follow-up longer than 5 years. Exclusion criteria were: any coexisting 
chronic cornea-conjunctival disease, unilateral cataract surgery, other mono- or bilateral intraocular surgery or refractive surgery, unilateral chronic use of preserved eyedrops, glaucoma therapy or other topical therapy. Confocal microscopy examination was performed according to a standard procedure.[11-13] Endothelial cell density (no. of cells $/ \mathrm{mm}^{2}$ ), pleomorphism (percentage of hexagonal cells) and polymegatism (percentage of oversized cells) were automatically calculated selecting the best-focused image (Fig $1 \mathrm{~A})$. Anterior stromal keratocyte density (cells $/ \mathrm{mm}^{2}$ ) was manually calculated selecting the first focused image of corneal stroma (Fig 1B). [11-13] Epithelium thickness was defined as the distance between the last focused image of the subbasal nerve plexus and the last focused image of the corneal epithelium, as described by Li et al.[14] Subbasal nerve plexus was evaluated choosing the best focused image of this structure.[13] Nerve fiber density $\left(\mu \mathrm{m} / \mathrm{mm}^{2}\right.$ ), number of fibers (fibers/field) and number of beadings (beadings $/ 100 \mu \mathrm{m}$ ) were quantified. Nerve fibers were traced using Neuron J program ${ }^{\odot}$, an image processing computer tool, to outline nerve fibers from each corneal sub-basal nerve plexus frame (Fig 1C).[13] Nerve fiber density was calculated for each image as the total length of the nerves (in micrometers) divided by the area of the image $\left(0.132 \mathrm{~mm}^{2}\right)$ and expressed as micrometers per square millimetre $\left(\mu \mathrm{m} / \mathrm{mm}^{2}\right)$.[13] Nerve fibers number was calculated as the total number of principal nerve trunks seen in the selected (best focused) image.[13] Number of beadings was manually calculated as the number of well-defined hyper-reflective points per unit of length $(100 \mu \mathrm{m})$ in a single nerve fiber, randomly selected from the best-focused fibers (Fig 1D).[13] Fellow eye was also evaluated and considered as a control.

\section{Statistical analysis}

Data about corneal endothelium density, pleomorphism and polymegatism, keratocyte density, number and density of nerve fibers, beadings and epithelial thickness in treated eyes were compared to the data obtained in fellow eyes using Student's paired t-test.

\section{RESULTS}

Forty-one consecutive patients with a mean age at treatment of $65.5 \pm 10.2$ years (range, 44-88) were included. Demographic data, tumor characteristics and cytologic results are reported in Table 1. 
Table 1: demographic data, tumor characteristics and cytologic results.

\begin{tabular}{|c|c|c|c|c|c|c|c|c|c|c|}
\hline$\#$ & GENDER & EYE & AGE & LOCATION & LBD & NODULARITY & VASCULARITY & MULTIFOCALITY & $\mathrm{FI}$ & CYTOLOGY \\
\hline 1 & $M$ & $\mathrm{RE}$ & 77 & $\mathrm{CC}$ & 5 & & & & & LGD \\
\hline 2 & $\mathrm{~F}$ & $\mathrm{RE}$ & 56 & CONJUNCTIVA & 6 & & & & & HGD \\
\hline 3 & $M$ & LE & 55 & $\mathrm{CC}$ & 5 & & & & & SCC \\
\hline 4 & M & LE & 80 & $\mathrm{CC}$ & 7 & & & & & SCC \\
\hline 5 & $\mathrm{~F}$ & $\mathrm{RE}$ & 73 & CORNEA & 8 & & + & & & HDD \\
\hline 6 & $\mathrm{~F}$ & LE & 77 & $\mathrm{CC}$ & 14 & + & + & & & LGD \\
\hline 7 & M & RE & 67 & $\mathrm{CC}$ & 25 & & & + & + & $\mathrm{SCC}$ \\
\hline 8 & $\mathrm{~F}$ & LE & 78 & CONJUNCTIVA & 12 & + & + & & & $\mathrm{SCC}$ \\
\hline 9 & M & LE & 73 & $\mathrm{CC}$ & 15 & & & & & LGD \\
\hline 10 & M & LE & 71 & $\mathrm{CC}$ & 6 & & & & & SCC \\
\hline 11 & M & $\mathrm{RE}$ & 58 & $\mathrm{CC}$ & 7 & & & & & HGD \\
\hline 12 & $\mathrm{~F}$ & $\mathrm{RE}$ & 59 & CONJUNCTIVA & 7 & & & & & $\mathrm{scc}$ \\
\hline 13 & M & LE & 66 & $\mathrm{CC}$ & 12 & & + & & & LGD \\
\hline 14 & $\mathrm{~F}$ & LE & 74 & $\mathrm{CC}$ & 14 & & + & & & HGD \\
\hline 15 & $\mathrm{~F}$ & $\mathrm{RE}$ & 66 & $\mathrm{CC}$ & 3 & & & & & LGD \\
\hline 16 & M & $\mathrm{RE}$ & 62 & $\mathrm{CC}$ & 11 & + & & & & $\mathrm{SCC}$ \\
\hline 17 & M & LE & 75 & CONJUNCTIVA & 7 & & & & & HGD \\
\hline 18 & $M$ & LE & 59 & $\mathrm{CC}$ & 7 & + & + & & & $\mathrm{ScC}$ \\
\hline 19 & $M$ & LE & 72 & $\mathrm{CC}$ & 18 & & & + & + & LGD \\
\hline 20 & $M$ & LE & 74 & $\mathrm{CC}$ & 5 & & & & & HGD \\
\hline 21 & $\mathrm{~F}$ & LE & 68 & $\mathrm{CC}$ & 7 & & & & & SCC \\
\hline 22 & $M$ & LE & 69 & CONJUNCTIVA & 6 & & & & & HGD \\
\hline 23 & M & LE & 64 & $\mathrm{CC}$ & 4 & & & & & HGD \\
\hline 24 & $\mathrm{~F}$ & LE & 65 & CONJUNCTIVA & 3 & & & & & SCC \\
\hline 25 & $M$ & $\mathrm{RE}$ & 77 & $\mathrm{CC}$ & 7 & + & & & & $\mathrm{scc}$ \\
\hline 26 & M & $\mathrm{RE}$ & 80 & $\mathrm{CC}$ & 15 & + & + & + & + & HGD \\
\hline 27 & $\mathrm{~F}$ & $\mathrm{RE}$ & 56 & $\mathrm{CC}$ & 3 & & & & & $\mathrm{SCC}$ \\
\hline 28 & $\mathrm{~F}$ & LE & 70 & $\mathrm{CC}$ & 17 & & & & & HGD \\
\hline 29 & M & $\mathrm{RE}$ & 59 & $\mathrm{CC}$ & 6 & & & & & HGD \\
\hline 30 & M & LE & 52 & CONJUNCTIVA & 9 & + & + & & & $\mathrm{SCC}$ \\
\hline 31 & $M$ & $\mathrm{RE}$ & 56 & CONJUNCTIVA & 11 & + & & & & $\mathrm{SCC}$ \\
\hline 32 & M & $\mathrm{RE}$ & 88 & CONJUNCTIVA & 4 & & & & & $\mathrm{SCC}$ \\
\hline 33 & $M$ & LE & 70 & $\mathrm{CC}$ & 12 & + & + & & & $\mathrm{SCC}$ \\
\hline 34 & M & $\mathrm{RE}$ & 34 & $\mathrm{CC}$ & 6 & & & & & HGD \\
\hline 35 & $\mathrm{~F}$ & $\mathrm{RE}$ & 80 & CONJUNCTIVA & 7 & & & & & $\mathrm{scc}$ \\
\hline 36 & $\mathrm{~F}$ & $\mathrm{RE}$ & 49 & $\mathrm{CC}$ & 13 & & + & & & LGD \\
\hline 37 & M & $\mathrm{RE}$ & 60 & $\mathrm{CC}$ & 3 & & & & & SCC \\
\hline 38 & $\mathrm{~F}$ & LE & 61 & $\mathrm{CC}$ & 3 & & & & & HGD \\
\hline 39 & $\mathrm{~F}$ & LE & 65 & CONJUNCTIVA & 5 & & & & & $\mathrm{SCC}$ \\
\hline 40 & M & $\mathrm{RE}$ & 77 & $\mathrm{CC}$ & 14 & & & & & HGD \\
\hline 41 & $M$ & LE & 53 & $\mathrm{CC}$ & 16 & + & + & & + & $\mathrm{scc}$ \\
\hline
\end{tabular}

${ }^{*} \mathrm{LBD}=$ Largest basal diameter; FI=Fornix involvement; $\mathrm{M}=$ Male; F=Female; RE= Right eye;

$\mathrm{LE}=\mathrm{Left}$ eye; $\mathrm{CC}=$ Cornea and conjunctiva; $\mathrm{LGD}=$ Low-grade dysplasia; $\mathrm{HGD}=$ High-grade dysplasia; SCC= Squamous cell carcinoma. 
Twenty-six patients were male (63.4\%) and fifteen were female (34.5\%). The right eye was affected in nineteen patients (58.6\%) and the left eye in twenty-two (36.6\%). Twenty-nine tumors (70.7\%) were corneo-conjunctival in location, one (2.4\%) corneal and eleven (26.8\%) were conjunctival. Mean tumor largest basal diameter was $8.9 \pm 5.0 \mathrm{~mm}$ (range, 3-25 mm). Baseline scraping cytology results were: low-grade dysplasia in seven cases (17.1\%), high-grade dysplasia in fourteen cases (34.1\%) and squamous cell carcinoma in twenty cases (48.8\%). Twenty-two patients (53.7\%) underwent 5-FU as a sole treatment, whereas nineteen patients (46.3\%) underwent 5-FU as a surgical-combined approach. Of these, topical chemotherapy was used as a debulking treatment in one case $(2.1 \%)$, as adjuvant therapy in fifteen cases $(36.6 \%)$ or as a double treatment (debulking + adjuvant) in seven cases (17.1\%). Histologic examination of all excided lesions confirmed baseline cytological diagnosis. Complete regression was achieved in all treated patients. Three patients (7.3\%), treated with 5-FU as a sole therapy, developed early recurrences during follow-up. These patients were successfully re-treated with additional courses of chemotherapy. Mean 1\% 5-FU courses number before definitive regression was 1.9 (range, 15). Mean follow-up was $89.7 \pm 14.4$ months (range, 63-122). Average age of disease onset, mean chemotherapy courses, mean follow-up and recurrences rate related to baseline cytology are reported in Table 2.

Table 2: Clinical and demographic characteristics related to baseline cytology.

\begin{tabular}{lcccc}
\hline & $\begin{array}{c}\text { Low-grade } \\
\text { dysplasia }\end{array}$ & $\begin{array}{c}\text { High-grade } \\
\text { dysplasia }\end{array}$ & Squamous cell & carcinoma \\
& $7(17.1 \%)$ & $14(34.1 \%)$ & $20(48.8 \%)$ & 41 \\
No. Of eye & $3 / 4$ & $7 / 7$ & $9 / 11$ & $19 / 22$ \\
Eyes (RE/LE) & $3 / 4$ & $5 / 9$ & $7 / 13$ & $15 / 26$ \\
Gender (female/male) & $64.4 \pm 9.1$ years & $64.4 \pm 10.6$ years & $68.7 \pm 10.3$ years & $65.5 \pm 10.2$ years \\
Average age of onset & 1.7 (Range, 1-3) & 1.8 (Range, 1-5) & 2.0 (Range, 1-5) & 1.9 (Range, 1-5) \\
Mean treatment courses & $0 \%$ & $7.1 \%$ & $10 \%$ & $7.3 \%$ \\
Recurrences rate & $88.2 \pm 14.6$ months & $90.1 \pm 14.9$ months & $89.9 \pm 14.3$ months & $89.7 \pm 14.4$ months \\
Mean follow-up & & & &
\end{tabular}


Confocal microscopy analysis of both eyes was successfully conduced in all patients. No significant differences were observed between treated eye and fellow/control eye in: endothelial cells density, endothelial pleomorphism and polymegatism, mean keratocyte density, mean corneal nerve density, mean subbasal nerve fibers number/fields, mean nerve beadings number and mean epithelial thickness. Confocal microscopy analysis results are reported on Table 3.

Table 3: Confocal microscopy analysis

\begin{tabular}{|c|c|c|c|}
\hline & $\begin{array}{c}\text { TREATED } \\
\text { EYES }\end{array}$ & $\begin{array}{c}\text { FELLOW- } \\
\text { CONTROL EYES }\end{array}$ & P VALUE* \\
\hline Endothelial cells density (cells $/ \mathrm{mm}^{2}$ ) & $2796 \pm 330$ & $2927 \pm 296$ & $P=0.084$ \\
\hline Endothelial pleomorphism (\%) & $56.7 \pm 12.3$ & $53.1 \pm 11.6$ & $P=0.174$ \\
\hline Endothelial polymegatism (\%) & $29.1 \pm 9.3$ & $29.8 \pm 9.7$ & $P=0.068$ \\
\hline Keratocyte density (cells $/ \mathrm{mm}^{2}$ ) & $530 \pm 97$ & $493 \pm 83$ & $P=0.067$ \\
\hline Epithelial thickness $(\mu \mathrm{m})$ & $50.5 \pm 8.1$ & $52.8 \pm 6.3$ & $P=0.155$ \\
\hline Subbasal nerve fibers (number/fields) & $4.2 \pm 1.6$ & $4.0 \pm 1.5$ & $P=0.561$ \\
\hline Subbasal nerve density $\left(\mu \mathrm{m} / \mathrm{mm}^{2}\right)$ & $10093 \pm 3715$ & $11052 \pm 3398$ & $P=0.126$ \\
\hline Subbasal nerve beadings (numbers $/ 100 \mu \mathrm{m}$ ) & $12.1 \pm 2.7$ & $12.9 \pm 2.2$ & $P=0.145$ \\
\hline
\end{tabular}

*Student' s paired t-test.

\section{DISCUSSION}

The main treatment modality for OSSN remains wide surgical excision with cryotherapy (with accurate histological assessment of surgical margins) and amniotic membrane reconstruction for large tissue defects.[7-10] However, the long-term local recurrence rate remains high, ranging from $15 \%$ to $52 \%$, even when surgical margins of primary excision are free from malignant cells.[1] The recurrence rate associated with surgery is probably due to the difficulty in establishing clinically tumor free margins.[7] Unless an intraoperative frozen-section technique is used, residual tumor cells may remain. $[5,16]$ Moreover, epithelial tumors of the conjunctiva can be multifocal or diffuse, rendering focal treatments less effective in eradicating these lesions.[1, 17] These data prompted us to introduce topical chemotherapy, as a sole or combined treatment, in a routine clinical setting.[6, 9] 
5-FU is a cell cycle-specific pyrimidine analogue with cytotoxic properties due to its effect on both DNA and RNA.[18] It was first synthesized in 1957 by Dushinski et al. and was found to have significant activity against tumours of the gastrointestinal tract, head, neck and breast.[18-19] This drug was originally known for its widespread use as an anticancer agent, but its ability to reduce fibroblastic proliferation and subsequent scarring has made it an important adjunct in ocular and periorbital surgery.[18] 5-FU acts on rapidly proliferating epithelial cells and was therefore used as a topical treatment for pre-invasive OSSN as early as 1986.[20] Many reports confirm the efficacy of topical chemotherapy with 5-FU as a sole or combined treatment of OSSN.[3, 6, 9, 17, 21] Moreover, only transient, low to mild and self-limited side effects were reported.[6, 9-19] Poothullil et al, reviewing the use of topical medical therapies for ocular surface tumors, reported punctuate keratitis and hyperemia as the only side effects of topical 5-FU. Other side effects included small epithelial defects, their accompanying discomfort and erythema of the eyelid skin.[10] Topical corticosteroids were usually applied to improve tolerance during the treatment, and rarely (never in our experience) patients discontinued therapy because of 5-FU side effects.[6, 9-10] Although many reports suggest a short-term safety of topical chemotherapy with $5-\mathrm{FU}$, there are no data on a long-term base.[6, 9-10]

In-vivo evaluation of the ocular structures at high magnification (to distinguish microscopic cell details) has always been a challenge for ophthalmic clinicians and researchers, but microscopic studies have, until recently, been limited to ex-vivo investigation. Confocal microscopy was introduced in the clinical practice as a non-invasive tool to observe at high magnification the structure of human cornea and conjunctiva in-vivo.[11, 12-13] CCM analysis extends, in-vivo, the principles of biomicroscopy to the microscopic range, scanning tissue layer by layer, by changing the plane of focus of the detector source.[11, 12-13] Confocal microscopy was previously used to analyze in detail corneal pathological changes secondary to ocular surface disease[22], refractive surgery[23], chronic use of topical therapy[24], systemic disease[12] and systemic pharmacological therapy[25] with promising results.

Panda et al have recently analyzed the effect of topical MMC on corneal endothelium in 25 patients affected by OSSN using endothelial specular microscopy. These Authors reported that topical $0.04 \% \mathrm{MMC}$ eyedrops do not significantly affect corneal endothelium. However they 
suggested that long-term data are mandatory.[26] Moreover, this study has analyzed only endothelium and not the other corneal layers. To the best of our knowledge the present study is the first focusing on long-term safety of topical chemotherapy using full thickness clinical confocal microscopy. Our data, obtained in-vivo in a fully non-invasive way, shows no long-term corneal toxicity in eyes treated with topical chemotherapy with 1\% 5-FU. Using clinical confocal microscopy we have confirmed that 5-FU is selective for neoplastic cells, demonstrating no long-term pathological change in corneal endothelium, epithelium, stroma and subbasal nerve plexus structures. These data, paired to clinical outcome of patients, suggest that topical chemotherapy with $1 \% 5$-FU should be considered a long-term safe and effective method as a sole or combined treatment of selected OSSN.

\section{Acknowledgment: none}

Competing interest: none declared

\section{Funding: none}

\section{Licence for Publication}

The Corresponding Author has the right to grant on behalf of all authors and does grant on behalf of all authors, an exclusive licence (or non exclusive for government employees) on a worldwide basis to the BMJ Publishing Group Ltd to permit this article (if accepted) to be published in BJO and any other BMJPGL products and sublicences such use and exploit all subsidiary rights, as set out in our licence (http://group.bmj.com/products/journals/instructions-for-authors/licence-forms). 


\section{REFERENCES}

1. Lee GA, Hurst LW. Ocular surface squamous neoplasia. Surv Ophthalmol 1995;39:429-50.

2. Basti S, Macsai MS. Ocular surface squamous neoplasia: a review. Cornea 2003;22:687704.

3. Napora C, Cohen EJ, Genvert GI, et al. Factors associated with conjunctival intraepithelial neoplasia: a case control study. Ophthalmic Surg 1990;21:27-30.

4. Nolan GR, Hirst LW, Wright RG, et al. Application of impression cytology to the diagnosis of conjunctival neoplasms. Diagn Cytopathol 1994;11:246-249.

5. Tunc M, Char DH, Crawford B, et al. Intraepithelial and invasive squamous cell carcinoma of the conjunctiva: analysis of 60 cases. Br J Ophthalomol 1999;83:98-103.

6. Midena E, Degli Angeli C, Valenti M, et al. Treatment of conjunctival squamous cell carcinoma with topical 5-fluorouracil. Br J Ophthalmol 2000;84:268-72.

7. Karp CL, Moore JK, Rosa RH Jr. Treatment of conjunctival and corneal intraepithelial neoplasia with topical interferon alpha-2b. Ophthalmology 2001;108:1093-8.

8. Frucht-Pery J, Sugar J, Baum J, et al. Mitomycin C treatment for conjunctival-corneal intraepithelial neoplasia: a multicenter experience. Ophthalmology 1997;104:2085-93.

9. Midena E, Boccato P, Angeli CD. Conjunctival squamous cell carcinoma treated with topical 5-fluoruracil. Arch Ophthalmol 1997;115:1600-1.

10. Poothullil AM, Colby KA. Topical medical therapies for ocular surface tumors. Semin Ophthalmol 2006;21:161-9.

11. Brugin E, Ghirlando A, Gambato C, et al. Central Corneal thickness Z-Ring Corneal Confocal Microscopy Versus Ultrasound Pachimetry. Cornea 2007;26:303-307.

12. Midena E, Brugin E, Ghirlando A, et al. Corneal diabetic neuropathy: a confocal microscopy study. J Refract Surg 2006;22 (s2):1047-52.

13. Midena E, Cortese M, Miotto S, et al. Confocal microscopy of sub-basal nerve plexus: a quantitative and qualitative analisys in healthy and pathologic eyes. J Refractiv Surg 2009;25 (s9):S125-30.

14. Li HF, Petroll WM, Moller-Pedersen T et al. Epithelial and corneal thickness measurements by in vivo confocal microscopy through focusing (CMTF). Current eye research 
$1997 ; 16: 214-221$

15. Meijering E, Jacob M, Sarria JC, et al: Design and validation of a tool for neurite tracing and analysis in fluorescence microscopy images. Cytometry A. 2004;58:167-176

16. Buus DR, Tse DT, Folberg R. Microscopically controlled excision of conjunctival squamous cell carcinoma. Am J Ophthalmol 1994;117: 97-102.

17. Yeatts RP, Engelbrecht NE, Curry CD, et al. 5-Fluorouracil for the treatment of intraepithelial neoplasia of the conjunctiva and cornea. Ophthalmol 2000;107:2190-5.

18. Abraham LM, Selva D, Casson R, et al. The clinical applications of fluorouracil in ophthalmic practice. Drugs 2007;67:237-255.

19. Dushinski R, Pleven E, Heidelberger C. The synthesis of 5 fluoro pyrimidines. J Am Chem Soc $1957 ; 79: 4559-60$.

20. de Keizer RJW, de Wolff-Rouendall D, van Delft JL. Topical application of 5-fluorouracil in premalignant lesions of cornea, conjunctiva and eyelid. Doc Ophthalmol 1986;64:31-42.

21. Yamamoto N, Ohmura T, Suzuki H, et al. Successful treatment with 5-fluorouracil of conjunctival intraepithelial neoplasia refractive to mitomycin-C. Ophthalmology 2002;109:249-52.

22. Wakamatsu TH, Sato EA, Matsumoto $\mathrm{Y}$, et al. Conjunctival in vivo confocal scanning laser microscopy in patients with Siogren syndrome. Invest Ophthalmol Vis Sci 2010:51;144-50.

23. Midena E, Gambato C, Miotto S et al. Long-term effects on corneal keratocytes of mitomycin $\mathrm{C}$ during photorefractive keratectomy: a randomized contralateral eye confocal microscopy study. J Refract Surg. 2007;23(Suppl):S1011-4.

24. Whitson JT, Cavanagh HD, Lakshaman N, et al. Assessment of corneal epithelial integrity after acute exposure to ocular hypotensive agents preserved with and without benzalkonium chloride. Adv Ther 2006;23:663-71.

25. Falke, Buttner A, Schittkowsky M, et al. The microstructure of cornea verticillata in Fabry disease and amiodarone-induced keratopathy: a confocal laser-scanning microscopy study. Graefes Arch Clin Exp Ophthalmol. 2009:247;523-34. 
26. Panda A, Pe'er J, Aggarwal A et al. Effect of topical mitomycin C on corneal endothelium. Am J Ophthalmol. 2008;145:635-638 
Fig 1. Corneal confocal microscopy analysis (using ConfoScan 4.0) in a patient treated with 1\% 5-FU. Endothelial cells were automatically selected, marked and analyzed by the software (A). Anterior stromal keratocyte density was manually calculated by the operator marking each one on-focus keratocyte (B). Nerve fibers were analyzed using Neuron $\mathrm{J}$ program $^{\odot}(\mathrm{C})$. Number of nerve beadings was manually calculated as the number of welldefined hyper-reflective points per unit of length $(100 \mu \mathrm{m})$ in a single nerve fibre. 


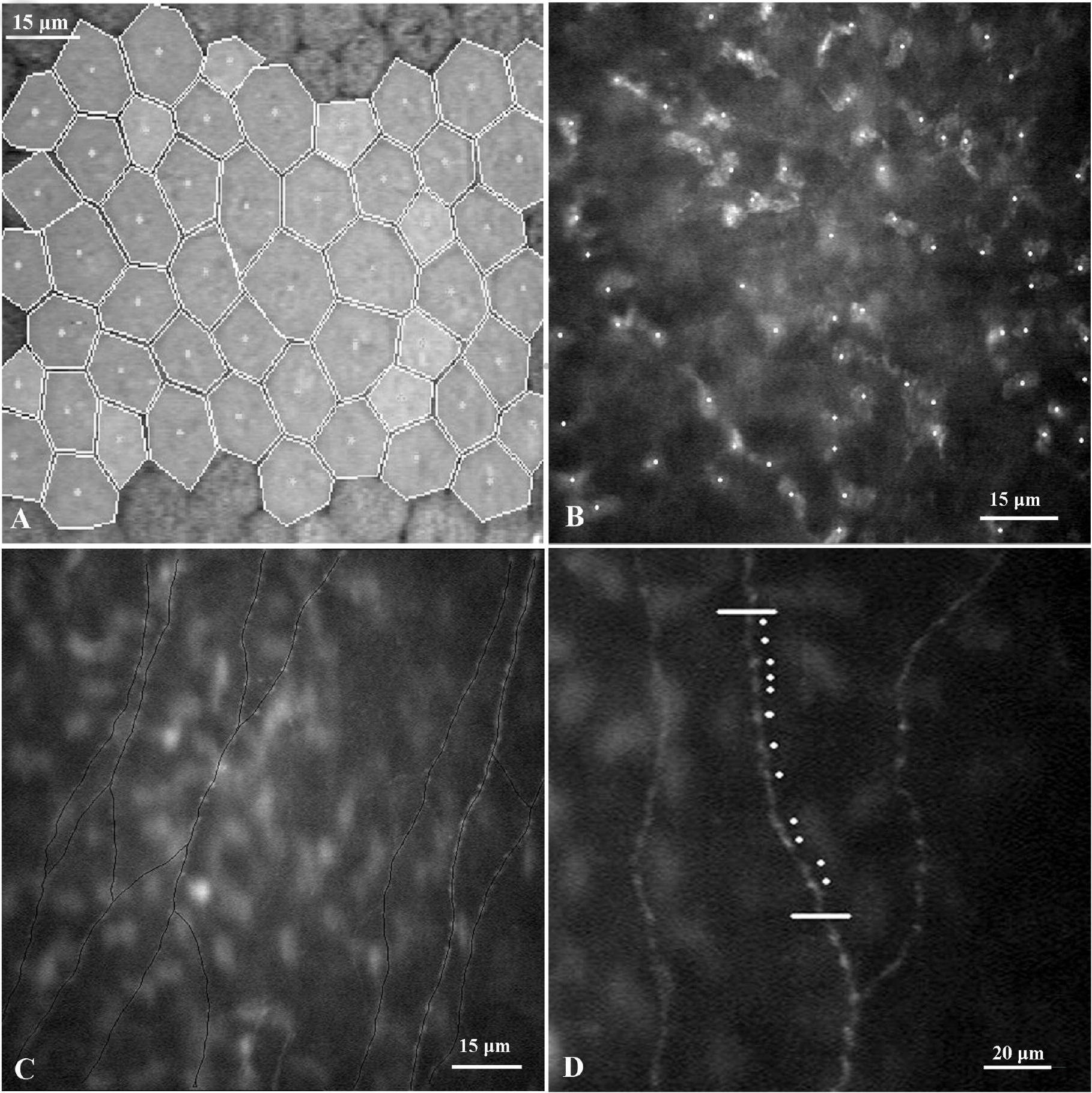

